\title{
A scientometrics survey on project scheduling
}

\author{
M. R. Ghaeli ${ }^{\mathrm{a} *}$ and Soheil Sadi-Nezhad ${ }^{\mathrm{b}}$
}

${ }^{a}$ Department of Commerce and Business Administration, New Westminster, BC, Canada ${ }^{b}$ Department of Statistics and Actuarial Science, University of Waterloo, Waterloo, Canada

CH R O N I C E A B S T R A C T

Article history:

Received: October 282018

Received in revised format: November 252018

Accepted: January 232019

Available online:

January 232019

Keywords:

Project scheduling

Highly cited

Country

Scientometrics
In project management, a schedule is considered as a list a project's milestones, activities, and deliverables, normally with some start and finish time schedule, which are estimated by some information incorporated in the project schedule including resource allocation, budget, task duration, and linkages of dependencies and scheduled events. This paper presents a comprehensive review of the studies associated with project scheduling. The study uses Scopus database as a primary search engine and covers 3370 records over the period 1963-2019. The records are statistically analyzed and categorized in terms of different criteria. Based on the survey, "decision support systems" is the keyword which has carried the highest densities followed by heuristics methods. Among the most cited articles, papers published by researchers in Germany have received the highest citations (9084), followed by United States (7058) and Belgium with 4853 citations.

\section{Introduction}

In project management, a schedule is considered as list a project's milestones, activities, and deliverables, normally with some start and finish time schedule, which are estimated by some information incorporated in the project schedule including resource allocation, budget, task duration, and linkages of dependencies and scheduled events. Any schedule is normally implemented in the project planning and project portfolio management as parts of project management. Elements on a schedule are associated with different issues such as the work breakdown structure (WBS) terminal elements, the statement of work, etc. Project scheduling has been used in the literature for years (Krauss, 1963; Moshman et al., 1963; Betzig, 1964). The object of project scheduling and management is to produce a complete project by considering the client's desires. In several cases, the primary object of project management is to change the client's brief to address the client's objectives. When the client's targets become transparent, they ought to influence all decisions made by other parties involved in the project such as project managers, designers, contractors, etc. This paper presents an overview on studies associated with project scheduling. The study uses Scopus database as a primary search engine and analyzes the data over the period 1963-2019.

* Corresponding author.

E-mail address: rghaeli@nyit.edu (M. R. Ghaeli) 


\section{The most common keywords}

Table 1 demonstrates some of the mostly cited references associated with project scheduling. As we can observe from the results of Table 1, Scheduling, Project scheduling and Project management are three well recognized keywords used in the literature. Fig. 1 shows the most important words used over times.

Table 1

The most popular keywords used in studies associated with project scheduling

\begin{tabular}{|c|c|c|c|}
\hline Terms & Frequency & Terms & Frequency \\
\hline scheduling & 1210 & activity duration & 50 \\
\hline project scheduling & 674 & combinatorial optimization & 49 \\
\hline project management & 446 & makespan & 48 \\
\hline optimization & 394 & project duration & 48 \\
\hline problem solving & 319 & computer software & 47 \\
\hline algorithms & 316 & critical path analysis & 47 \\
\hline $\begin{array}{l}\text { resource-constrained project scheduling } \\
\text { problem }\end{array}$ & 298 & iterative methods & 46 \\
\hline genetic algorithms & 258 & precedence constraints & 45 \\
\hline resource allocation & 241 & tabu search & 44 \\
\hline heuristic methods & 236 & uncertainty analysis & 44 \\
\hline constraint theory & 194 & random processes & 43 \\
\hline scheduling algorithms & 182 & production control & 42 \\
\hline mathematical models & 171 & decision support systems & 40 \\
\hline project scheduling problem & 167 & priority rules & 40 \\
\hline resource constrained project scheduling & 156 & resource constraints & 40 \\
\hline costs & 128 & local search & 39 \\
\hline integer programming & 122 & mathematical programming & 38 \\
\hline heuristic algorithms & 100 & resource-constrained project scheduling & 37 \\
\hline constrained optimization & 99 & construction management & 36 \\
\hline decision making & 99 & critical chain & 36 \\
\hline computational complexity & 93 & rcpsp & 36 \\
\hline construction industry & 92 & managers & 35 \\
\hline artificial intelligence & 91 & production engineering & 35 \\
\hline resource constraint & 84 & strategic planning & 35 \\
\hline evolutionary algorithms & 83 & heuristics & 34 \\
\hline operations research & 82 & construction & 33 \\
\hline resource-constrained & 82 & critical path method & 32 \\
\hline computer simulation & 81 & economic and social effects & 32 \\
\hline computational results & 80 & precedence relations & 32 \\
\hline multi-project scheduling & 79 & project activities & 32 \\
\hline construction projects & 76 & heuristic programming & 31 \\
\hline computational experiment & 74 & software engineering & 31 \\
\hline benchmarking & 66 & dynamic programming & 30 \\
\hline particle swarm optimization (pso) & 63 & flow measurement & 30 \\
\hline scheduling problem & 63 & industrial engineering & 30 \\
\hline computer programming & 62 & product development & 30 \\
\hline simulated annealing & 62 & constraint programming & 29 \\
\hline multiobjective optimization & 61 & graph theory & 29 \\
\hline linear programming & 60 & meta heuristics & 29 \\
\hline stochastic systems & 59 & np-hard & 29 \\
\hline fuzzy sets & 58 & objective functions & 29 \\
\hline computational methods & 57 & optimization problems & 29 \\
\hline pert & 57 & multi agent systems & 28 \\
\hline $\begin{array}{l}\text { multi-mode resource-constrained project } \\
\text { scheduling problem }\end{array}$ & 54 & project managers & 28 \\
\hline net present value & 54 & project planning & 28 \\
\hline multimodes & 52 & uncertainty & 28 \\
\hline planning & 52 & optimal solutions & 27 \\
\hline
\end{tabular}




\section{Contributions of countries}

Our survey demonstrates that European countries have maintained the most contribution in the field of project scheduling. Table 2 shows details of our survey.

\section{Table 2}

The summary of the contributions of different countries

\begin{tabular}{|c|c|c|}
\hline Country & Total Citations & Average Article Citations \\
\hline GERMANY & 9084 & 63.52 \\
\hline USA & 7058 & 29.05 \\
\hline BELGIUM & 4853 & 55.15 \\
\hline CHINA & 2816 & 10.71 \\
\hline SPAIN & 1919 & 35.54 \\
\hline IRAN & 1829 & 15.12 \\
\hline FRANCE & 1618 & 24.15 \\
\hline POLAND & 1348 & 18.99 \\
\hline TURKEY & 1110 & 27.75 \\
\hline TAIWAN & 1100 & 21.57 \\
\hline CANADA & 1070 & 23.26 \\
\hline UNITED KINGDOM & 794 & 30.54 \\
\hline ITALY & 723 & 21.26 \\
\hline INDIA & 682 & 14.51 \\
\hline HONG KONG & 667 & 37.06 \\
\hline AUSTRALIA & 646 & 16.56 \\
\hline JAPAN & 637 & 19.91 \\
\hline ISRAEL & 513 & 21.38 \\
\hline KOREA & 460 & 21.90 \\
\hline GREECE & 448 & 23.58 \\
\hline SINGAPORE & 437 & 23.00 \\
\hline PORTUGAL & 262 & 18.71 \\
\hline THAILAND & 246 & 22.36 \\
\hline AUSTRIA & 232 & 23.20 \\
\hline BRAZIL & 232 & 15.47 \\
\hline SOUTH AFRICA & 190 & 95.00 \\
\hline CZECH REPUBLIC & 176 & 22.00 \\
\hline TUNISIA & 172 & 17.20 \\
\hline NETHERLANDS & 167 & 12.85 \\
\hline LEBANON & 163 & 81.50 \\
\hline SAUDI ARABIA & 149 & 37.25 \\
\hline HUNGARY & 138 & 9.20 \\
\hline COLOMBIA & 119 & 17.00 \\
\hline QATAR & 109 & 54.50 \\
\hline SWITZERLAND & 108 & 12.00 \\
\hline CHILE & 84 & 9.33 \\
\hline ARMENIA & 80 & 40.00 \\
\hline ARGENTINA & 69 & 17.25 \\
\hline EGYPT & 66 & 9.43 \\
\hline NEW ZEALAND & 56 & 11.20 \\
\hline MALAYSIA & 45 & 9.00 \\
\hline NORWAY & 44 & 14.67 \\
\hline SWEDEN & 38 & 38.00 \\
\hline NIGERIA & 29 & 7.25 \\
\hline CYPRUS & 28 & 5.60 \\
\hline FINLAND & 19 & 9.50 \\
\hline SLOVENIA & 17 & 5.67 \\
\hline CAMEROON & 14 & 4.67 \\
\hline DENMARK & 14 & 14.00 \\
\hline LITHUANIA & 11 & 5.50 \\
\hline IRELAND & 10 & 5.00 \\
\hline BELARUS & 9 & 9.00 \\
\hline CROATIA & 9 & 2.25 \\
\hline MEXICO & 8 & 8.00 \\
\hline PAKISTAN & 7 & 3.50 \\
\hline LUXEMBOURG & 6 & 6.00 \\
\hline INDONESIA & 2 & 2.00 \\
\hline KUWAIT & 2 & 2.00 \\
\hline VENEZUELA & 2 & 2.00 \\
\hline
\end{tabular}




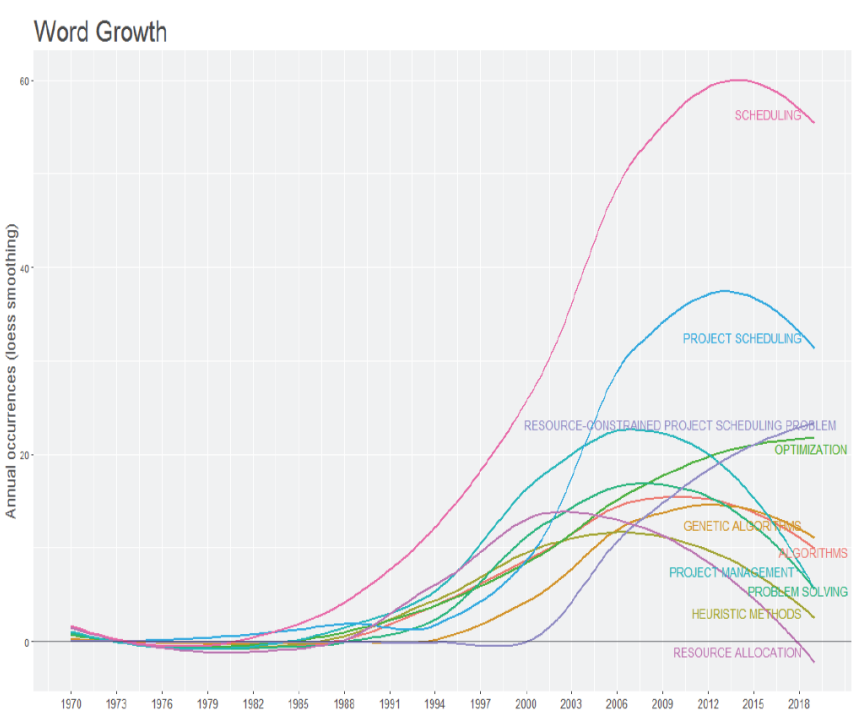

Fig. 1. The summary of the most popular keywords used in project scheduling

According to Table 2, researchers from Germany have published 9084 papers followed by United States with 7058 papers and Belgium with 4853 papers. In terms of the average citation, papers published by researchers in Germany and Belgium have maintained the highest citations. Fig. 3 shows the results of the collaborations among various countries.

Country Collaboration Map

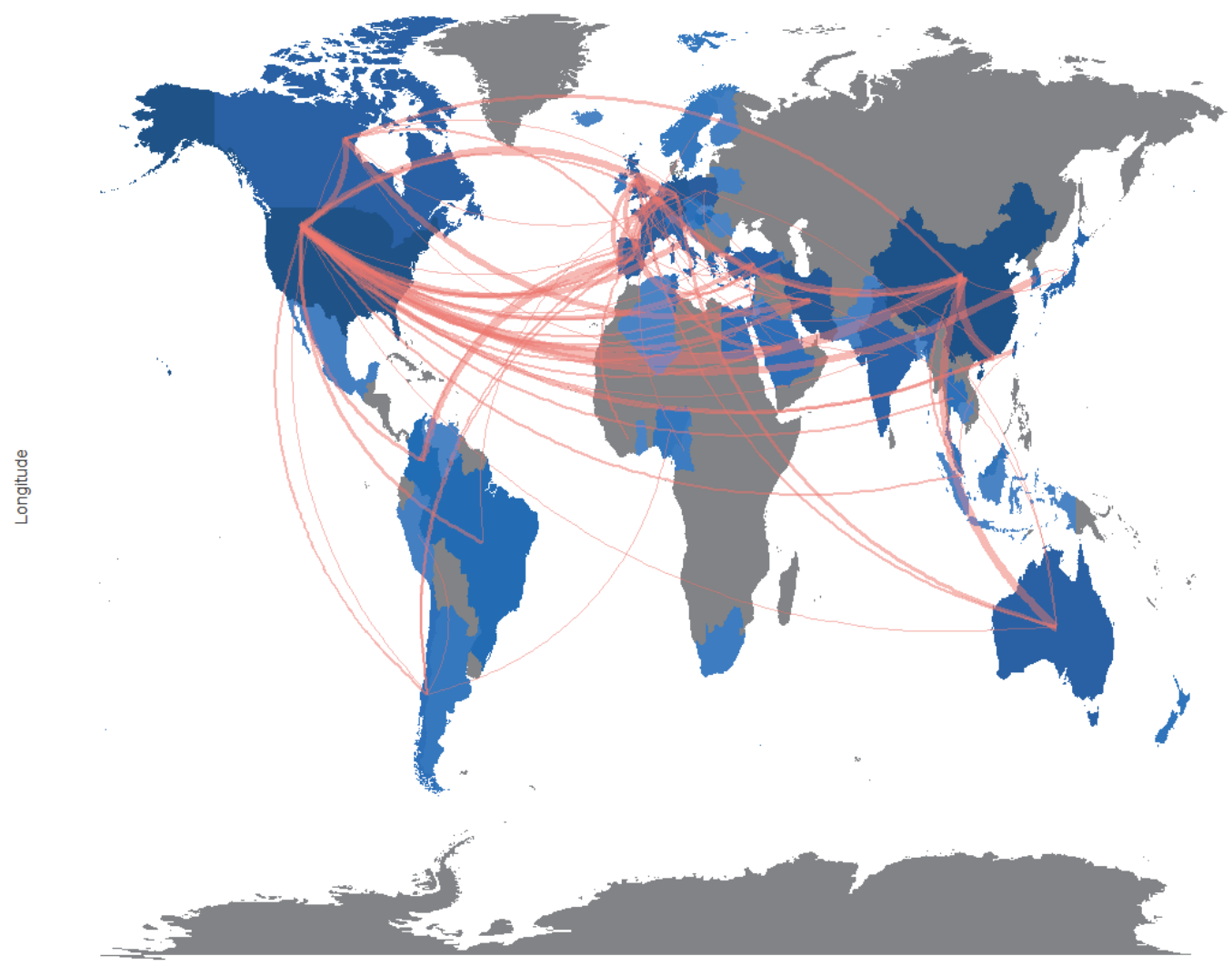

Fig. 3. Country collaboration map 
As we can observe from the results of Fig. 3, there were strong collaboration from the researchers in United States from one side and other countries.

\section{Highly cited papers}

Table 3 shows the summary of the most cited articles. As we can observe from the results of Table 3 , the study by Brucker et al. (1999) has received the highest citations. In their study, they provided a classification scheme, i.e. an explanation for the resource environment, the activity characteristics, and the objective function, respectively, which is consistent with machine scheduling and helps classify the most important models. They also proposed a unifying notation to review some of the recent developments such as exact and heuristic algorithms for the single-mode and the multi-mode case, for the time-cost tradeoff problem, etc. The second highly cited work is associated with Kolisch and Drexl (1997) where they provided a local search for non-preemptive multi-mode resource-constrained project scheduling. They proposed a general class of non-preemptive resourceconstrained project scheduling problems where activity durations were discrete functions of committed renewable and nonrenewable resources. They obtained a 0-1 problem formulation and explained the model by applying applications within production and operations management. In addition, they proved that the feasibility problem which is NP-complete and could hardly deal with some shortcomings. Thus, they proposed a new local search method that initially attempt to locate a feasible solution and then executed a single-neighborhood search on the set of feasible mode assignments. They also performed a computational study on two benchmark sets where the experiment included a comparison of the procedure with other heuristics. The third highly cited work belongs to Herroelen and Leus (2005) where they investigated a project scheduling under uncertainty. The other highly cited paper was accomplished by Merkle et al. (2002) which was a metaheuristics method named ant colony optimization for resource-constrained project scheduling. Hartmann (2010) in his remarkable work provided a competitive genetic algorithm for resource-constrained project scheduling. This work is one of the well-known non-review paper which has received a high citation and the average citation per year was also the highest for this item. A close look at the highly cited works listed in Table 3 reveals that many of them were associated with meta-heuristics methods ((Boctor, 1990, 1993; Boctor, 1996; Bouleimen \& Lecocq, 2003; Debels et al., 2006; Debels \& Vanhoucke, 2007; Gonçalves et al., 2008; Hartmann, 1998; Hartmann, 2001; Hartmann, 2002; Józefowska et al., 2001). This can be also verified in Fig. 4 where genetic algorithm has been used significantly.

\section{Table 3}

The summary of the most cited articles

\begin{tabular}{lcc}
\hline Paper & Total Citations & TC per Year \\
\hline BRUCKER P, 1999, EUR J OPER RES & 952 & 47.6 \\
KOLISCH R, 1997, EUR J OPER RES & 692 & 31.4545 \\
HERROELEN W, 2005, EUR J OPER RES & 562 & 40.1429 \\
MERKLE D, 2002, IEEE TRANS EVOL COMPUT & 483 & 28.4118 \\
KOLISCH R, 2006, EUR J OPER RES & 467 & 35.9231 \\
HARTMANN S, 2010, EUR J OPER RES & 428 & 47.5556 \\
KOLISCH R, 1996, EUR J OPER RES & 422 & 18.3478 \\
HARTMANN S, 1998, NAV RES LOGIST & 372 & 17.7143 \\
HERROELEN W, 1998, COMPUT OPER RES & 359 & 17.0952 \\
BOULEIMEN K, 2003, EUR J OPER RES & 341 & 21.3125 \\
HARTMANN S, 2000, EUR J OPER RES & 327 & 17.2105 \\
MUSA JD, 1975, IEEE TRANS SOFTWARE ENG & 316 & 7.1818 \\
DAVIS EW, 1975, MANAGE SCI & 315 & 7.1591 \\
KOO B, 2000, J CONSTR ENG MANAGE & 301 & 15.8421 \\
KOLISCH R, 2001, OMEGA & 295 & 16.3889 \\
TALBOT FBRIAN, 1982, MANAGE SCI & 262 & 7.0811 \\
PATTERSON JH, 1984, MANAGE SCI & 261 & 7.4571 \\
CHO SH, 2005, IEEE TRANS ENG MANAGE & 241 & 17.2143 \\
BAKER KR, 2009, PRINC OF SEQUENCING AND SCHEDULING & 22.5 \\
CHRISTOFIDES N, 1987, EUR J OPER RES & 225 & 6.9062 \\
DEBELS D, 2006, EUR J OPER RES & 221 & 16.5385 \\
JARBOUI B, 2008, APPL MATH COMPUT & 215 & 19.3636 \\
MINGOZZI A, 1998, MANAGE SCI & 213 & 10.0476
\end{tabular}


ÖZDAMAR L, 1995, IIE TRANS BRUCKER P, 1998, EUR J OPER RES

VALLS V, 2005, EUR J OPER RES

HARTMANN S, 2002, NAV RES LOGIST

GONÇALVES JF, 2008, EUR J OPER RES

KOLISCH R, 1996, J OPER MANAGE

IP WH, 2003, COMP OPER RES

LI KY, 1992, EUR J OPER RES

PETEGHEM VV, 2010, EUR J OPER RES

ALCARAZ J, 2001, ANN OPER RES

BOCTOR FF, 1990, EUR J OPER RES

KURTULUS I, 1982, MANAGE SCI

HARTMANN S, 2001, ANN OPER RES

ZHOU X, 2007, TRANSP RES PART B METHODOL

DEMEULEMEESTER EL, 1997, MANAGE SCI

RODAMMER FA, 1988, IEEE TRANS SYST MAN CYBERN

WGLARZ J, 2011, EUR J OPER RES

VALLS V, 2008, EUR J OPER RES

HERROELEN W, 2004, INT J PROD RES

MENDES JJM, 2009, COMP OPER RES

CESTA A, 2002, J HEURISTICS

ALBA E, 2007, INF SCI

SPRECHER A, 1998, EUR J OPER RES

ZHANG H, 2005, AUTOM CONSTR

ADELI H, 1997, J CONSTR ENG MANAGE

SPRECHER A, 1995, EUR J OPER RES

DAVIS EW, 1973, AIIE TRANS

KHANZODE A, 2008, ELECTRON J INF TECHNOL CONSTR

DEMEULEMEESTER E, 2003, J SCHEDULING

ALCARAZ J, 2003, J OPER RES SOC

AL-FAWZAN MA, 2005, INT J PROD ECON

ARTIGUES C, 2003, EUR J OPER RES

ÖZDAMAR L, 1999, IEEE TRANS SYST MAN CYBERN PT C APPL

SPRECHER A, 1997, OR SPECTRUM

SAIDI-MEHRABAD M, 2007, INT J ADV MANUF TECHNOL

ZHOU X, 2005, EUR J OPER RES

TUKEL OI, 2006, EUR J OPER RES

VAN DE VONDER S, 2005, INT J PROD ECON

MORI M, 1997, EUR J OPER RES

MOORTHY R, 2006, OR SPECTRUM

MIKA M, 2005, EUR J OPER RES

TORMOS P, 2001, ANN OPER RES

KOLISCH R, 1997, IIE TRANS

ZHANG H, 2006, INT J PROJ MANAGE

MÖHRING RH, 2003, MANAGE SCI

LEE JK, 1996, J OPER RES SOC

LEVNER E, 2010, COMPUT IND ENG

LONG LD, 2008, INT J PROJ MANAGE

WANG D, 2001, IEEE TRANS SYST MAN CYBERN PT C APPL REV

HERROELEN WS, 1997, EUR J OPER RES

VAN DE VONDER S, 2008, EUR J OPER RES

BOCTOR FF, 1993, INT J PROD RES

BOCTOR FF, 1996, INT J PROD RES

YANG XS, 2011, COMMUN COMPUT INFO SCI

BROWNING TR, 2010, INT J PROD ECON

LOVA A, 2009, INT J PROD ECON

DREXL A, 1991, MANAGE SCI

NONOBE K, 2002, OPER RES COMPUT SCI INTERFACES SER

DOERSCH RH, 1977, MANAGE SCI

SENOUCI AB, 2001, J CONSTR ENG MANAGE

DE REYCK B, 1998, EUR J OPER RES

DEBELS D, 2007, OPER RES

JÓZEFOWSKA J, 2001, ANN OPER RES

STEYN H, 2001, INT J PROJ MANAGE

KATEHAKIS MN, 1987, MATH OPER RES

\begin{tabular}{|c|c|}
\hline 211 & 8.7917 \\
\hline 196 & 9.3333 \\
\hline 184 & 13.1429 \\
\hline 184 & 10.8235 \\
\hline 182 & 16.5455 \\
\hline 176 & 7.6522 \\
\hline 173 & 10.8125 \\
\hline 173 & 6.4074 \\
\hline 171 & 19 \\
\hline 171 & 9.5 \\
\hline 171 & 5.8966 \\
\hline 171 & 4.6216 \\
\hline 170 & 9.4444 \\
\hline 158 & 13.1667 \\
\hline 157 & 7.1364 \\
\hline 154 & 4.9677 \\
\hline 153 & 19.125 \\
\hline 152 & 13.8182 \\
\hline 152 & 10.1333 \\
\hline 151 & 15.1 \\
\hline 151 & 8.8824 \\
\hline 149 & 12.4167 \\
\hline 148 & 7.0476 \\
\hline 147 & 10.5 \\
\hline 146 & 6.6364 \\
\hline 146 & 6.0833 \\
\hline 145 & 3.1522 \\
\hline 142 & 12.9091 \\
\hline 142 & 8.875 \\
\hline 137 & 8.5625 \\
\hline 133 & 9.5 \\
\hline 132 & 8.25 \\
\hline 128 & 6.4 \\
\hline 128 & 5.8182 \\
\hline 127 & 10.5833 \\
\hline 125 & 8.9286 \\
\hline 124 & 9.5385 \\
\hline 124 & 8.8571 \\
\hline 123 & 5.5909 \\
\hline 120 & 9.2308 \\
\hline 120 & 8.5714 \\
\hline 120 & 6.6667 \\
\hline 118 & 5.3636 \\
\hline 117 & 9 \\
\hline 117 & 7.3125 \\
\hline 115 & 5 \\
\hline 114 & 12.6667 \\
\hline 114 & 10.3636 \\
\hline 113 & 6.2778 \\
\hline 112 & 5.0909 \\
\hline 109 & 9.9091 \\
\hline 109 & 4.1923 \\
\hline 108 & 4.6957 \\
\hline 107 & 13.375 \\
\hline 107 & 11.8889 \\
\hline 107 & 10.7 \\
\hline 106 & 3.7857 \\
\hline 105 & 6.1765 \\
\hline 105 & 2.5 \\
\hline 103 & 5.7222 \\
\hline 103 & 4.9048 \\
\hline 102 & 8.5 \\
\hline 102 & 5.6667 \\
\hline 102 & 5.6667 \\
\hline 102 & 3.1875 \\
\hline
\end{tabular}




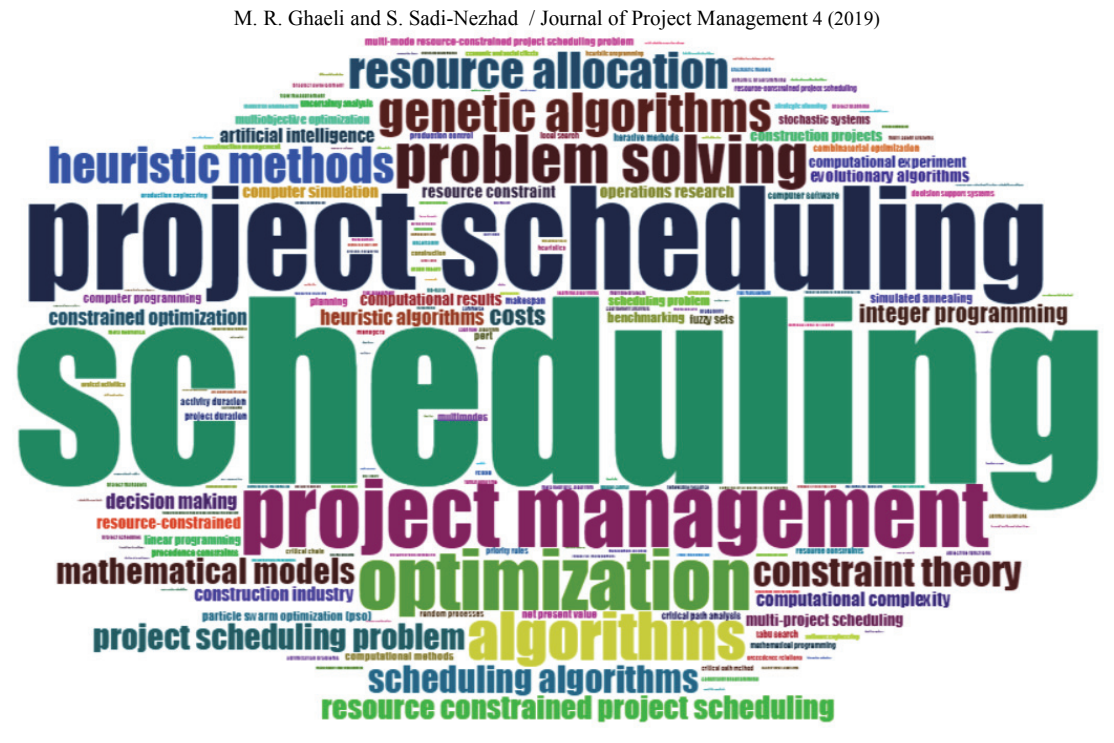

Fig. 4. The frequency of the keywords used in different project scheduling studies

\section{Contribution of the countries}

One of the interesting areas of the interest is to learn more about the contribution of different countries in project scheduling. As we can observe from the results of Fig. 5, researchers from China (537 papers), United States (487 papers), Iran (257 papers) and Germany (215) have contributed the most on project scheduling.

\section{Country Scientific Production}

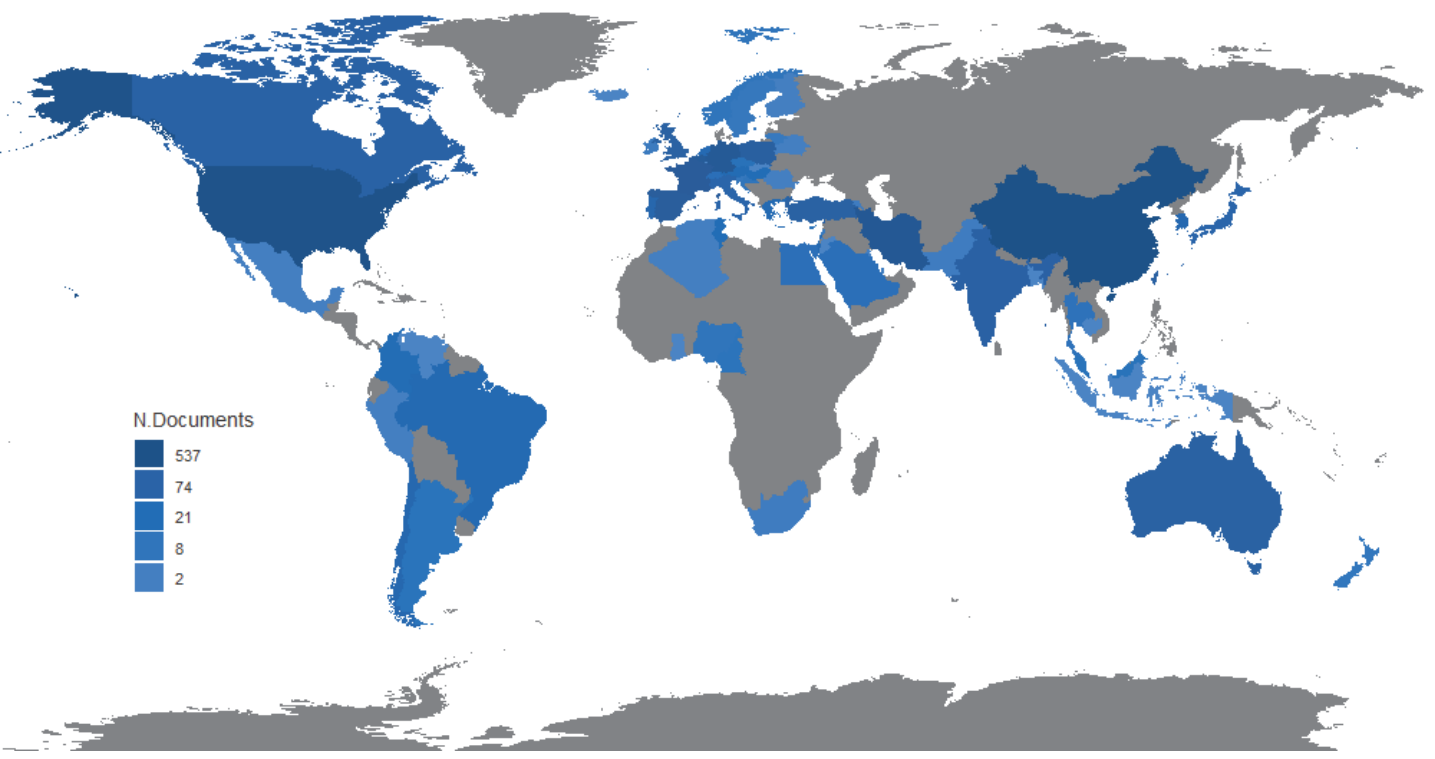

Fig. 5. The frequency of the keywords used in different project scheduling studies

\section{Conclusion}

This study has tried to provide a comprehensive review of the studies published in the literature associated with project scheduling. The study has indicated that this field has been popular mostly among researchers in United States, China, Germany and Iran. The study has also indicated that while researchers from Germany published a relatively high number of papers, they were also suc- 
cessful to publish highly cited papers. Many project scheduling studies have dealt with combinatorial optimization techniques and our survey has concluded that meta-heuristics methods have been popular among researchers to locate the near-optimal solutions. We hope this study could guide other researchers find important research gaps.

\section{References}

Adeli, H., \& Karim, A. (1997). Scheduling/cost optimization and neural dynamics model for construction. Journal of Construction Engineering and Management, 123(4), 450-458.

Alba, E., \& Chicano, J. F. (2007). Software project management with GAs. Information Sciences, 177(11), 2380-2401.

Alcaraz, J., \& Maroto, C. (2001). A robust genetic algorithm for resource allocation in project scheduling. Annals of operations Research, 102(1-4), 83-109.

Alcaraz, J., Maroto, C., \& Ruiz, R. (2003). Solving the multi-mode resource-constrained project scheduling problem with genetic algorithms. Journal of the Operational Research Society, 54(6), 614-626.

Al-Fawzan, M. A., \& Haouari, M. (2005). A bi-objective model for robust resource-constrained project scheduling. International Journal of production economics, 96(2), 175-187.

Artigues, C., Michelon, P., \& Reusser, S. (2003). Insertion techniques for static and dynamic resource-constrained project scheduling. European Journal of Operational Research, 149(2), 249267.

Baker, K. R., \& Trietsch, D. (2013). Principles of sequencing and scheduling. John Wiley \& Sons.

Brucker, P., Drexl, A., Möhring, R., Neumann, K., \& Pesch, E. (1999). Resource-constrained project scheduling: Notation, classification, models, and methods. European journal of operational research, 112(1), 3-41.

Betzig, H. M. (1964). Earlier payout through tight project scheduling and control. Journal of the American Oil Chemists' Society, 41(3), 58-58.

Boctor, F. F. (1990). Some efficient multi-heuristic procedures for resource-constrained project scheduling. European journal of operational research, 49(1), 3-13.

Boctor, F. F. (1993). Heuristics for scheduling projects with resource restrictions and several resource-duration modes. The international journal of production research, 31(11), 2547-2558.

Boctor, F. F. (1996). Resource-constrained project scheduling by simulated annealing. International Journal of Production Research, 34(8), 2335-2351.

Bouleimen, K. L. E. I. N., \& Lecocq, H. O. U. S. N. I. (2003). A new efficient simulated annealing algorithm for the resource-constrained project scheduling problem and its multiple mode version. European Journal of Operational Research, 149(2), 268-281.

Brucker, P., Knust, S., Schoo, A., \& Thiele, O. (1998). A branch and bound algorithm for the resource-constrained project scheduling problem1. European Journal of Operational Research, 107(2), 272-288.

Browning, T. R., \& Yassine, A. A. (2010). Resource-constrained multi-project scheduling: Priority rule performance revisited. International Journal of Production Economics, 126(2), 212-228.

Cho, S. H., \& Eppinger, S. D. (2005). A simulation-based process model for managing complex design projects. IEEE Transactions on engineering management, 52(3), 316-328.

Christofides, N., Alvarez-Valdés, R., \& Tamarit, J. M. (1987). Project scheduling with resource constraints: A branch and bound approach. European Journal of Operational Research, 29(3), 262-273.

Cesta, A., Oddi, A., \& Smith, S. F. (2002). A constraint-based method for project scheduling with time windows. Journal of Heuristics, 8(1), 109-136.

Damak, N., Jarboui, B., Siarry, P., \& Loukil, T. (2009). Differential evolution for solving multimode resource-constrained project scheduling problems. Computers \& Operations Research, 36(9), 2653-2659.

Davis, E. W. (1973). Project scheduling under resource constraints-historical review and categorization of procedures. AIIE Transactions, 5(4), 297-313. 
Davis, E. W., \& Patterson, J. H. (1975). A comparison of heuristic and optimum solutions in resource-constrained project scheduling. Management science, 21(8), 944-955.

Debels, D., De Reyck, B., Leus, R., \& Vanhoucke, M. (2006). A hybrid scatter search/electromagnetism meta-heuristic for project scheduling. European Journal of Operational Research, 169(2), 638-653.

Debels, D., \& Vanhoucke, M. (2007). A decomposition-based genetic algorithm for the resourceconstrained project-scheduling problem. Operations Research, 55(3), 457-469.

Demeulemeester, E. L., \& Herroelen, W. S. (1997). New benchmark results for the resource-constrained project scheduling problem. Management Science, 43(11), 1485-1492.

Demeulemeester, E., Vanhoucke, M., \& Herroelen, W. (2003). RanGen: A random network generator for activity-on-the-node networks. Journal of scheduling, 6(1), 17-38.

De Reyck, B. (1998). A branch-and-bound procedure for the resource-constrained project scheduling problem with generalized precedence relations. European Journal of Operational Research, 111(1), 152-174.

Doersch, R. H., \& Patterson, J. H. (1977). Scheduling a project to maximize its present value: A zero-one programming approach. Management Science, 23(8), 882-889.

Drexl, A. (1991). Scheduling of project networks by job assignment. Management Science, 37(12), $1590-1602$.

Fleszar, K., \& Hindi, K. S. (2004). Solving the resource-constrained project scheduling problem by a variable neighbourhood search. European Journal of Operational Research, 155(2), 402-413.

Gonçalves, J. F., Mendes, J. J., \& Resende, M. G. (2008). A genetic algorithm for the resource constrained multi-project scheduling problem. European Journal of Operational Research, 189(3), 1171-1190.

Hartmann, S. (1998). A competitive genetic algorithm for resource-constrained project scheduling. Naval Research Logistics (NRL), 45(7), 733-750.

Hartmann, S., \& Kolisch, R. (2000). Experimental evaluation of state-of-the-art heuristics for the resource-constrained project scheduling problem. European Journal of Operational Research, 127(2), 394-407.

Hartmann, S. (2001). Project scheduling with multiple modes: a genetic algorithm. Annals of Operations Research, 102(1-4), 111-135.

Hartmann, S. (2002). A self-adapting genetic algorithm for project scheduling under resource constraints. Naval Research Logistics (NRL), 49(5), 433-448.

Hartmann, S., \& Briskorn, D. (2010). A survey of variants and extensions of the resource-constrained project scheduling problem. European Journal of operational research, 207(1), 1-14.

Herroelen, W. S., Van Dommelen, P., \& Demeulemeester, E. L. (1997). Project network models with discounted cash flows a guided tour through recent developments. European Journal of Operational Research, 100(1), 97-121.

Herroelen, W., De Reyck, B., \& Demeulemeester, E. (1998). Resource-constrained project scheduling: a survey of recent developments. Computers \& Operations Research, 25(4), 279-302.

Herroelen, W., \& Leus, R. (2004). Robust and reactive project scheduling: a review and classification of procedures. International Journal of Production Research, 42(8), 1599-1620.

Herroelen, W., \& Leus, R. (2005). Project scheduling under uncertainty: Survey and research potentials. European journal of operational research, 165(2), 289-306.

Ip, W. H., Huang, M., Yung, K. L., \& Wang, D. (2003). Genetic algorithm solution for a risk-based partner selection problem in a virtual enterprise. Computers \& Operations Research, 30(2), $213-$ 231.

Józefowska, J., Mika, M., Różycki, R., Waligóra, G., \& Węglarz, J. (2001). Simulated annealing for multi-mode resource-constrained project scheduling. Annals of Operations Research, 102(14), 137-155.

Levner, E., Kats, V., de Pablo, D. A. L., \& Cheng, T. E. (2010). Complexity of cyclic scheduling problems: A state-of-the-art survey. Computers \& Industrial Engineering, 59(2), 352-361.

Lee, J. K., \& Kim, Y. D. (1996). Search heuristics for resource constrained project scheduling. Journal of the Operational Research Society, 47(5), 678-689. 
Li, K. Y., \& Willis, R. J. (1992). An iterative scheduling technique for resource-constrained project scheduling. European Journal of Operational Research, 56(3), 370-379.

Long, L. D., \& Ohsato, A. (2008). Fuzzy critical chain method for project scheduling under resource constraints and uncertainty. International Journal of Project Management, 26(6), 688-698.

Lova, A., Tormos, P., Cervantes, M., \& Barber, F. (2009). An efficient hybrid genetic algorithm for scheduling projects with resource constraints and multiple execution modes. International Journal of Production Economics, 117(2), 302-316.

Jarboui, B., Damak, N., Siarry, P., \& Rebai, A. (2008). A combinatorial particle swarm optimization for solving multi-mode resource-constrained project scheduling problems. Applied Mathematics and Computation, 195(1), 299-308.

Katehakis, M. N., \& Veinott Jr, A. F. (1987). The multi-armed bandit problem: decomposition and computation. Mathematics of Operations Research, 12(2), 262-268.

Kolisch, R. (1996). Serial and parallel resource-constrained project scheduling methods revisited: Theory and computation. European Journal of Operational Research, 90(2), 320-333.

Kolisch, R. (1996). Efficient priority rules for the resource-constrained project scheduling problem. Journal of Operations Management, 14(3), 179-192.

Kolisch, R., \& Drexl, A. (1997). Local search for nonpreemptive multi-mode resource-constrained project scheduling. IIE transactions, 29(11), 987-999.

Kolisch, R., \& Sprecher, A. (1997). PSPLIB-a project scheduling problem library: OR softwareORSEP operations research software exchange program. European journal of operational research, 96(1), 205-216.

Kolisch, R., \& Padman, R. (2001). An integrated survey of deterministic project scheduling. Omega, 29(3), 249-272.

Kolisch, R., \& Hartmann, S. (2006). Experimental investigation of heuristics for resource-constrained project scheduling: An update. European journal of operational research, 174(1), 23 37.

Koo, B., \& Fischer, M. (2000). Feasibility study of 4D CAD in commercial construction. Journal of construction engineering and management, 126(4), 251-260.

Krauss, W. (1963). Über die Terminplanung großer Entwicklungsvorhaben. Unternehmensforschung, 7(4), 151-168.

Kurtulus, I. B. R. A. H. I. M. S., \& Davis, E. W. (1982). Multi-project scheduling: Categorization of heuristic rules performance. Management Science, 28(2), 161-172.

Merkle, D., Middendorf, M., \& Schmeck, H. (2002). Ant colony optimization for resource-constrained project scheduling. IEEE transactions on evolutionary computation, 6(4), 333-346.

Mendes, J. J. D. M., Gonçalves, J. F., \& Resende, M. G. (2009). A random key based genetic algorithm for the resource constrained project scheduling problem. Computers \& Operations Research, 36(1), 92-109.

Mika, M., Waligóra, G., \& Węglarz, J. (2005). Simulated annealing and tabu search for multi-mode resource-constrained project scheduling with positive discounted cash flows and different payment models. European Journal of Operational Research, 164(3), 639-668.

Mingozzi, A., Maniezzo, V., Ricciardelli, S., \& Bianco, L. (1998). An exact algorithm for the resource-constrained project scheduling problem based on a new mathematical formulation. Management science, 44(5), 714-729.

Moorthy, R., \& Teo, C. P. (2007). Berth management in container terminal: the template design problem. In Container Terminals and Cargo Systems (pp. 63-86). Springer, Berlin, Heidelberg.

Mori, M., \& Tseng, C. C. (1997). A genetic algorithm for multi-mode resource constrained project scheduling problem. European Journal of Operational Research, 100(1), 134-141.

Moshman, J., Johnson, J., \& Larsen, M. (1963, May). RAMPS: a technique for resource allocation and multi-project scheduling. In Proceedings of the May 21-23, 1963, spring joint computer conference (pp. 17-27). ACM.

Möhring, R. H., Schulz, A. S., Stork, F., \& Uetz, M. (2003). Solving project scheduling problems by minimum cut computations. Management Science, 49(3), 330-350. 
Musa, J. D. (1975). A theory of software reliability and its application. IEEE transactions on software engineering, (3), 312-327.

Nonobe, K., \& Ibaraki, T. (2002). Formulation and tabu search algorithm for the resource constrained project scheduling problem. In Essays and surveys in metaheuristics (pp. 557-588). Springer, Boston, MA.

Olofsson, T., Lee, G., Eastman, C., \& Reed, D. (2007). Benefits and lessons learned of implementing building virtual design and construction (VDC) technologies for coordination of mechanical, electrical, and plumbing.

Özdamar, L., \& Ulusoy, G. (1995). A survey on the resource-constrained project scheduling problem. IIE transactions, 27(5), 574-586.

Ozdamar, L. (1999). A genetic algorithm approach to a general category project scheduling problem. IEEE Transactions on Systems, Man, and Cybernetics, Part C (Applications and Reviews), 29(1), 44-59.

Patterson, J. H. (1984). A comparison of exact approaches for solving the multiple constrained resource, project scheduling problem. Management science, 30(7), 854-867.

Rodammer, F. A., \& White, K. P. (1988). A recent survey of production scheduling. IEEE transactions on systems, man, and cybernetics, 18(6), 841-851.

Saidi-Mehrabad, M., \& Fattahi, P. (2007). Flexible job shop scheduling with tabu search algorithms. The International Journal of Advanced Manufacturing Technology, 32(5-6), 563-570.

Senouci, A. B., \& Adeli, H. (2001). Resource scheduling using neural dynamics model of Adeli and Park. Journal of Construction Engineering and Management, 127(1), 28-34.

Sprecher, A., Hartmann, S., \& Drexl, A. (1997). An exact algorithm for project scheduling with multiple modes. Operations-Research-Spektrum, 19(3), 195-203.

Sprecher, A., \& Drexl, A. (1998). Multi-mode resource-constrained project scheduling by a simple, general and powerful sequencing algorithm1. European Journal of Operational Research, 107(2), 431-450.

Steyn, H. (2002). Project management applications of the theory of constraints beyond critical chain scheduling. International Journal of Project Management, 20(1), 75-80.

Talbot, F. B. (1982). Resource-constrained project scheduling with time-resource tradeoffs: The nonpreemptive case. Management science, 28(10), 1197-1210.

Tormos, P., \& Lova, A. (2001). A competitive heuristic solution technique for resource-constrained project scheduling. Annals of Operations Research, 102(1-4), 65-81.

Tukel, O. I., Rom, W. O., \& Eksioglu, S. D. (2006). An investigation of buffer sizing techniques in critical chain scheduling. European Journal of Operational Research, 172(2), 401-416.

Valls, V., Ballestín, F., \& Quintanilla, S. (2005). Justification and RCPSP: A technique that pays. European Journal of Operational Research, 165(2), 375-386.

Valls, V., Ballestin, F., \& Quintanilla, S. (2008). A hybrid genetic algorithm for the resource-constrained project scheduling problem. European Journal of Operational Research, 185(2), 495508.

Van Peteghem, V., \& Vanhoucke, M. (2010). A genetic algorithm for the preemptive and nonpreemptive multi-mode resource-constrained project scheduling problem. European Journal of Operational Research, 201(2), 409-418.

Van de Vonder, S., Demeulemeester, E., Herroelen, W., \& Leus, R. (2005). The use of buffers in project management: The trade-off between stability and makespan. International Journal of production economics, 97(2), 227-240.

Van de Vonder, S., Demeulemeester, E., \& Herroelen, W. (2008). Proactive heuristic procedures for robust project scheduling: An experimental analysis. European Journal of Operational Research, 189(3), 723-733.

Wang, D., Yung, K. L., \& Ip, W. H. (2001). A heuristic genetic algorithm for subcontractor selection in a global manufacturing environment. IEEE Transactions on Systems, Man, and Cybernetics, Part C (Applications and Reviews), 31(2), 189-198. 
Węglarz, J., Józefowska, J., Mika, M., \& Waligóra, G. (2011). Project scheduling with finite or infinite number of activity processing modes-A survey. European Journal of operational research, 208(3), 177-205.

Yang, X. S., Deb, S., \& Fong, S. (2011, July). Accelerated particle swarm optimization and support vector machine for business optimization and applications. In International Conference on Networked Digital Technologies (pp. 53-66). Springer, Berlin, Heidelberg.

Zhang, H., Li, X., Li, H., \& Huang, F. (2005). Particle swarm optimization-based schemes for resource-constrained project scheduling. Automation in Construction, 14(3), 393-404.

Zhang, H., Li, H., \& Tam, C. M. (2006). Particle swarm optimization for resource-constrained project scheduling. International Journal of Project Management, 24(1), 83-92.

Zhou, X., \& Zhong, M. (2005). Bicriteria train scheduling for high-speed passenger railroad planning applications. European Journal of Operational Research, 167(3), 752-771.

Zhou, X., \& Zhong, M. (2007). Single-track train timetabling with guaranteed optimality: Branchand-bound algorithms with enhanced lower bounds. Transportation Research Part B: Methodological, 41(3), 320-341.

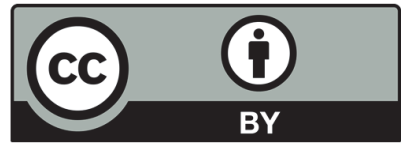

(C) 2019 by the authors; licensee Growing Science, Canada. This is an open access article distributed under the terms and conditions of the Creative Commons Attribution (CC-BY) license (http://creativecommons.org/licenses/by/4.0/). 